\title{
MERCY AND CAPRICE UNDER THE INDIAN CONSTITUTION
}

\author{
ADAM PERRY
}

\begin{abstract}
The Indian Constitution gives the executive the power to pardon offenders. The Supreme Court of India has repeatedly held that the executive must not grant or refuse pardons capriciously or arbitrarily. I raise two worries about this line of authority. The executive has its pardon powers in part so that it can show mercy. In one sense, mercy is about doing justice despite what the law requires. Were mercy in this sense shown consistently, it would imperil the rule of law. Caprice is the price of containing that threat. In another sense, mercy is about showing compassion despite what justice requires. Mercy in this sense is an act of grace, and caprice is the price of it being possible at all. By seeking to eliminate caprice, the Court has risked undermining the rule of law, and frustrating one of the aims of the Constitution.
\end{abstract}

KEYWORDS. Mercy, pardon, arbitrariness, capricious, Maru Ram

\section{INTRODUCTION}

After someone is charged with a crime may come a prosecution; after a prosecution may come a conviction; and after a conviction will almost certainly come a sentence, imposed by a judge. All that remains, as far as the criminal justice system is concerned, is for that sentence to be served. The stages of this process are predictable, and that predictability helps to make the process fair. But almost every legal system in the world makes possible extraordinary departures from this process, by giving an actor outside the criminal justice system, usually a senior member of the executive, the power to set aside or reduce a verdict or sentence.

The Indian Constitution is no exception. It gives the President and the Governor of each state a power to pardon offenders or to suspend, reduce, or remit their sentences. The decisions of the President and the Governors as to whether to exercise these powers rarely please everyone. Both those seeking relief and those resisting them have turned to the courts for aid - and the courts have obliged. In a series of cases beginning in the 1980s, the Supreme Court of India held that decisions to grant or refuse pardons and similar relief are amenable to judicial 
review. The rationale for review was the need to make these decisions more predictable, more rational, and above all, less capricious.

In this paper I raise two worries about the Supreme Court's jurisprudence concerning the powers to grant pardons and similar relief. As I explain, the executive has these powers in part so that it can show mercy. In one sense, mercy is about doing justice despite what the law requires. Mercy in this sense is a threat to the rule of law, and caprice is the price of containing that threat. In another sense, mercy is about showing compassion, despite what justice requires. Mercy in this sense is an act of grace, and caprice is the price of it being possible at all. I worry, therefore, that in seeking to tame executive power, and eliminate caprice, the Supreme Court has risked undermining the rule of law, or has frustrated one of the aims of the Constitution.

\section{Case Law AND ConTeXt}

Article 72 of the Constitution concerns the powers of the President. It reads in part:

1. The President shall have the power to grant pardons, reprieves, or remissions of punishment or suspend, or remit or commute the sentence of any person convicted of any offence

(a) in all cases where the punishment or sentence is by a court martial;

(b) in all cases where the punishment or sentence is for an offence against any law relating to any matter to which the executive power of the union extends;

(c) in all cases where the sentence is a sentence of death.

The Article goes on to state that it does not affect certain other powers to suspend, remit, or commute sentences. ${ }^{1}$

Article 161 concerns the powers of the Governor of a State, and reads in full:

The Governor of a State shall have the power to grant pardons, reprieves, respites or remissions of punishment or to suspend, remit or commute the sentence of any person convicted of any offence against any law relating to a matter of which the executive power of the State extends.

\footnotetext{
${ }^{1}$ Under Article 74(1), this powers is exercised by the President on the advice of the Council of Ministers and the Prime Minister. For an excellent account of the process by which this advice is produced and the role of the President, see BJ Batra, "'Court' of Last Resort: A Study of Constitutional Clemency for Capital Crimes in India' (2009) Working Paper Series, Centre for the Study of Law and Governance (J awaharlal Nehru University) 18-41, 58-80.
} 
Although the terms of arts. 72/ 161appear to give powers to the President and the Governors, these powers are effectively exercised by the relevant council of ministers, as required by art. 74 .

For present purposes the differences between arts. 72 and 161 are unimportant, as are the differences between pardons, suspensions, and remissions. So I shall tend to refer simply to 'the pardon powers' rather than to a particular power conferred under a particular article; and I shall refer to 'the executive' rather than to the President or to the Governors. I shall use the term 'pardon decision' to refer either to the exercise of a power under arts. 72/ 161 or to the refusal to exercise such a power. Finally, I shall set aside the complicated issues about the stage of criminal proceedings at which the arts. $72 / 161$ powers can be exercised, the exact legal effects of their exercise, and the offences with respect to which they can be exercised. ${ }^{2}$

My focus is judicial review of pardon decisions. Traditionally, Indian courts were reluctant to review pardon decisions. ${ }^{3}$ That began to change in 1980, with the Supreme Court's decision in Maru Ram v Union of India 4 . The Court acknowledged that the executive is owed a degree of latitude when it comes to pardon decisions. However, it said:

Wide as the [art. 72 power] ... is, it cannot run riot; for no legal power can run unruly like J ohn Gilpin on the horse but must keep sensibly to a steady course. ... [A]ll public power, including constitutional power, shall never be exercis[ed] arbitrarily or mala fide and, ordinarily, guidelines for fair and equal execution are guarantors of the valid play of power. We proceed on the basis that these axioms are valid in our constitutional order. 5

As an example of a factor that would invalidate an art. 72 decision, the Court mentioned a refusal motivated by a "political vendetta"6.

The Court in Maru Ram repeatedly emphasized the dangers of arbitrariness and capriciousness. Under the Constitution, the Court said, "all power, whatever its source, must, in its exercise, anathematise

2 On these issues, see: J P Rai, "Exercise of Pardon power in India: Emerging Challenges" (2014) 12 NEHU J ournal 1, 9-15; R Sahai, "Limits of the Pardon power Under the Indian Constitution" (2009) 2 NUJ S L Rev 283 at 286-292, 296-301.

${ }^{3}$ See, e.g., G. Krishta Goud and J. Bhoomaiah v. State of Andhra Pradesh and Ors. (1976) 1 SCC 157.

${ }^{4}$ Maru Ram v Union of India and Ors (1981) 1 SCC 107. The primary issue in Maru Ram was the constitutionality of s 433A of the Criminal Procedure Code.

${ }_{5}$ Maru Ram (n 4) 147 [62] (Krishna Iyer J, for himself Chandrachud CJ and Bhagwati J).

${ }^{6}$ Maru Ram (n 4) 149 [65].(Krishna Iyer J, for himself Chandrachud CJ and Bhagwati J). 
arbitrariness"7. Reliance on "capricious criteria"8 must render a pardon decision invalid. Anything else would amount to a rejection of reason and the rule of law. "Every action of the executive Government must be informed with reason", it said, and so must be "free from arbitrariness" 9 . Freedom from arbitrariness, according to the Court, is the "bare minimal requirement"10 and the "very essence"11 of the rule of law.

In the years since Maru Ram, the Supreme Court's jurisprudence concerning the pardon powers has evolved in many ways. The Court remains willing, however, to review pardon decisions, including for capriciousness. ${ }^{12}$ In the 2006 case of Epuru Sudhakar v Government of Andhra Pradesh ${ }^{13}$, for example, the Supreme Court said that it was "well-settled that the exercise or non-exercise of pardon power by the President or Governor, as the case may be, is not immune from judicial review" 14 . The Court summarized the relevant grounds of review as follows:

(a) that the order has been passed without application of mind;

(b) that the order is mala fide;

(c) that the order has been passed on extraneous or wholly irrelevant considerations;

(d) that relevant materials have been kept out of consideration;

(e) that the order suffers from arbitrariness. ${ }^{15}$

In this case, a murderer's sentence had been substantially remitted, and the victim's sons sought judicial review of the remission order. The Court invalidated the order for being based on theirrelevant consideration that the murderer was a "good Congress worker", as well as on other misleading information ${ }^{16}$.

In its decisions under arts. 72/161, the Supreme Court has often drawn on case law from the United States and the United Kingdom.

\footnotetext{
${ }^{7}$ Maru Ram (n 4) 148 [63].(Krishna Iyer J , for himself Chandrachud CJ and Bhagwati J).

8 Maru Ram (n 4) 149 [65].(Krishna Iyer J , for himself Chandrachud CJ and Bhagwati J).

${ }_{9}^{9}$ Maru Ram (n 4) 148 [63], quoting from Ramana Dayaram Shetty v International Airport Authority of India and Ors (1979) 3 SCC 489, 504 [10] (Bhagwati J).

10 Maru Ram (n 4) 148 [63], quoting from Ramana Dayaram Shetty v International Airport Authority of India and Ors (1979) 3 SCC 489, 504 [10] (Bhagwati J ).

${ }_{11}$ Maru Ram (n 4) 148 [63], quoting from Ramana Dayaram Shetty v International Airport Authority of India and Ors (1979) 3 SCC 489, 504 [10] (Bhagwati J ).

12 See, e.g., Kehar Singh and Anor v Union of India and Anor (1989) 1 SCC 204; Swaran Singh v State of Uttar Pradesh AIR 1998 SC 2026; Satpal v State of Haryana AIR 2000 SC 1702; Bikas Chaterjeev Union of India (2004) 7 SCC 634; Devender Pal Singh Bhullar v State of N.C.T. of Delhi [2013] INSC 424.

${ }^{13}$ Epuru Sudhakar and Anor. v Government of Andhra Pradesh and Ors (2006) 8 SCC 161.

${ }^{14}$ Epuru Sudhakar (n 13) 177 [22] (Pasayat J).

${ }^{15}$ Epuru Sudhakar (n 13) 181 [34] (Pasayat J).

${ }^{16}$ Epuru Sudhakar (n 13) 189 [56]-[59] (Pasayat J).
} 
What it has rarely noted is that until recently judicial review of pardoning decisions in those other jurisdictions has been unavailable, and even now it is more controversial than in India. In the United States, the traditional view, expressed by Marshall CJ in United States v Wilson 17, was that a pardon is "an act of grace"18 and thus unreviewable. J ustice Holmes disagreed in Biddle v Perovich ${ }^{19}$, where in a passage much cited by Indian courts he said that "a pardon in our days is not a private act of grace. It is a part of the Constitutional scheme"20. American law today sits somewhere between these two views, as can be seen in the 1998 case of Ohio Adult Parole Authority v Woodard21, in which the constitutionality of Ohio's clemency (pardon) procedures was at issue. ChiefJ ustice Rehnquist echoed Marshall CJ when he held that "the heart of executive clemency" is a "matter of grace"22. J ustice O'Connor led the majority in Woodard, however, and she held that a respect for due process requires that "some minimal procedural safeguards apply to clemency proceedings"23. For example, she said, judicial interventions would belegitimate if "a state official flipped a coin to determine whether to grant clemency" 24.

In the United Kingdom, the power to issue pardons is conferred by the prerogative power of mercy. Like all decisions under prerogative powers, pardon decisions were traditionally unreviewable. ${ }^{25}$ That changed, first, with the House of Lords' 1986 decision in Civil Service Union v Secretary of State for the Civil Service ${ }^{26}$, which held that decisions under most prerogative powers are reviewable, and then with the Divisional Court's 1993 decision in R v Secretary of State for the Home Department, ex p Bentley ${ }^{27}$, which held that pardon decisions are reviewable. Recently, lower courts in Britain have been willing to review pardon decisions on a range of grounds, including for inconsistency, failure to consider relevant factors, and failure to exercise genuine discretion. ${ }^{28}$ Over the same period, the J udicial Committee of the Privy Council ( $\mathrm{J} \mathrm{CPC}$ ') also changed its mind about the reviewability of pardon

\footnotetext{
17 United States v Wilson, 2 U.S. (7 Pet.) 150 (1883).

18 Wilson (n 17) 160.

${ }^{19}$ Biddlev Perovich, 274 U.S. 480 (1927).

20 Biddle (n 19) at 486.

${ }^{21}$ Ohio Adult Parole Authority v Woodard, 523 U.S. 272 (1998).

22 Woodard (n 21) 281.

23 Woodard (n 21) 289 (emphasis in original).

24 Woodard (n 21) 289.

${ }^{25}$ See, e.g., Hanratty v Lord Butler (1971) 115 SJ 386, 386 ("[t]helaw would not inquire into the manner in which [the] prerogative [of mercy] was exercised").

${ }^{26}$ Civil Service Union v Secretary of State for the Civil Service, [1985] A.C. 374

${ }^{27}$ R v Secretary of State for the Home Department, ex p Bentley [1994] 3 QB 349.

${ }^{28} \mathrm{R}$ (Page) v Secretary of State for J ustice [2007] EWHC 2026 (Admin) (failure to take into account a relevant factor); Re Dunn's Application for J udicial Review [2010] NIQB 54 (fettering discretion); McGeough v Secretary of State for Northern Ireland [2012] NICA 28 (consistency).
} 
decisions. In 1976, the JCPC had held in de Freitas v Benny 29 that pardon decisions are unreviewable. In a now infamous passage, Lord Diplock said that "mercy is not the subject of legal rights. It begins where legal rights end" 30 . In 2001, however, the J CPC reversed itself in Lewis v Attorney General of J amaica ${ }^{31}$. Lord Slynn for the majority held that pardon decisions are reviewable on procedural grounds. Moreover, if a pardon decision "is taken in an arbitrary or perverse way - on the throw of a dice or on the basis of a convicted man's hairstyle - or is otherwise arrived at an improper, unreasonable way, the court should prima facie be able to investigate" 32 .

In the United States and the United Kingdom (as well as in some other jurisdictions ${ }^{33}$ ), courts are now willing to review pardoning decisions for rather extreme forms of capriciousness, as in India. India was truly the pioneer in this respect, however, and India remains an outlier in the enthusiasm it shows for judicial review of pardoning decisions.

\section{CAPrice AND the Rule of LAW}

This trend towards greater reviewability of mercy decisions might look like a straightforward victory for the rule of law. What the rule of law seems to oppose above all else is arbitrary power, and it is one of the responsibilities of judges to uphold the rule of law. Thus, it may seem obvious that judges are merely doing their constitutional duty by reviewing pardon decisions for arbitrariness or capriciousness (I use the terms interchangeably in what follows). Pardon decisions concern vital matters - crime, punishment, sometimes life and death - and that would appear to make it all the more important that mercy decisions conform to the rule of law.

This way of thinking is comfortably in line with recent British case law, including Bentley; with the JCPC's ruling in Lewis; with Holmes J's statement in Biddle and O'Connor J's worries in Woodard; and with every decision of the Indian Supreme Court regarding pardon decisions since and including Maru Ram. The common denominator in these cases is the impression that pardon powers are, constitutionally

\footnotetext{
29 de Freitas v Benny [1976] AC 239.

30 de Freitas (n 29) 247-8.

${ }^{31}$ Lewis v Attorney General of J amaica [2001] 2 AC 50.

32 Lewis (n 31) 76.

33 Other common law jurisdictions to extend some form of judicial review to pardon decisions since Maru Ram was decided include Canada (Thatcher v Canada (Attorney General) [1997] 1 FC 289); Singapore (Yong Vui Kong v Attorney-General [2011] SGCA 9); and South Africa (Albutt v Centre for the Study of Violence and Reconciliation [2010] ZACC 4). For general discussion, see A Perry, 'Mercy and the Roles of J udges' in J 'Mercy and the Roles of J udges' in J J acobs and J J ackson (eds), Routledge Handbook of Criminal Justice Ethics (Routledge 2016); A Novak, Comparative Executive Clemency (Routledge 2015) c 8.
} 
speaking, rather unexceptional. The decision to grant or refuse a pardon are decisions under an executive power, and ought to be reviewable because decisions under all such powers ought to be reviewable.

I am skeptical, however. I worry that judges have overstated their competence to review mercy decisions. I think there is more to be said for the JCPC's decision in de Freitas, and for Marshall CJ's view in Wilson and Rehnquist CJ 's viewin Woodard, than has been appreciated. It will take me the next two sections to explain why, but I want to start with the sense in which capriciousness or arbitrariness offends the rule of law.

In general, a capricious or arbitrary decision is an unreasoned choice - a choice made for a whim not a reason. The capriciousness that offends the rule of law is more specific, however. As Timothy Endicott says, "[i]n the special sense in which arbitrariness is a departure from the rule of law, a decision is arbitrary whenever the law itself ought to demand a justification other than the fact that the decision maker made it, and there is no such justification" 34 . If the courts ought not to demand a justification for a decision other than that the appropriate decision maker made it, then that decision does not depart from the rule of law, even if it is made for irrelevant reasons, or for no reason at all. In other words, a decision can be capricious, in an ordinary sense of the term, without being contrary to the rule of law.

So, the important question is: ought courts to demand more justification for pardon decisions than that the executive has made them? I do not claim to have a complete answer to that question. What I offer, instead, is an argument for why capriciousness should be acceptable when a pardon is or would be an act of mercy.

34 TAO Endicott, "Arbitrariness" (2014) 17 Canadian J ournal of Law and J urisprudence 49, 71. 


\section{MerCy}

Pardon powers are familiar features of legal systems. No jurisdiction does without them. ${ }^{35}$ As a result, it is easy to lose sight of how strange they are. Matters of guilt and innocence, and sanctions and punishment, are the normal province of judges. J udges decide these matters, and their decisions are normally final. When one institution sets aside the decision of another institution, it is almost always the judiciary doing the setting aside. The pardon powers upend all this. They give the executive the final opportunity to show leniency, placing it above the judiciary on this one issue. What explains this anomaly?

The obvious thought is that the executive has pardon powers so that it can correct for the legal errors that courts will inevitably make. There are, of course, errors that the pardon powers do not allow the executive to correct: wrongful acquittals, sentences that are too lenient, errors unrelated to criminal matters, and perhaps others. The kind of legal errors that the pardon powers do allow the executive to correct wrongful convictions, sentences that are too harsh - may be the most serious, though. The need to avoid them may justify extraordinary safeguards. The executive then serves as a kind of 'court of last resort', in which capacity it supervises the work of courts proper, and remedies their most egregious errors. ${ }^{36}$

Perhaps this is part of the answer, but it is not the whole answer. The pardon powers are also given to the executive so that it can show mercy. I say this for four reasons. First, it is what the Indian courts say. ${ }^{37}$ Second, the pardon powers under the Indian Constitution are derived from the English prerogative power of 'mercy', and parallel provisions in many other constitutions are called 'mercy' powers. 38 Third, to show mercy, in

\footnotetext{
35 Apparently only one regime has officially abolished pardons - and that was for a short time, during the French Revolution of 1789. See K Moore, Pardons: J ustice, Mercy, and the Public Interest (OUP 1989) 24-25.

36 The Supreme Court seems to be of two minds about whether the executive may legitimately correct for legal errors by courts. On the one hand, in Kehar Singh (n 11) the Court said that the President was able "to scrutinise the evidence on the record of the criminal case and come to a different conclusion from that recorded by the Court in regard to the guilt of, and sentence imposed on, the accused" (at 212-213 [10] (Pathak CJ ). On the other hand, in the same case, the Court went on to say that the President acts on a "wholly different plane" from the Court, and his pardon power is "entirely different from the judicial power" (at 213 [10] (Pathak CJ). Moreover, in Naryan Dutt v State of Punjab (2011) 4 SCC 353, the Court invalidated a pardon in part because the Governor had expressed a view as to the innocence of the applicant, which the Court took to be a usurpation of the judicial role ([41]).

${ }^{37}$ See, e.g., Devender Pal Singh Bhullar v. State of N.C.T. of Delhi, [2013] INSC 424.

38 The connection between the English prerogative of mercy and the pardon powers under the Indian Constitution is acknowledged in Maru Ram (n 4) 145 [57] (Krishna Iyer J , for himself Chandrachud CJ and Bhagwati J ). See also the historical discussion by BJ Batra in "'Court' of Last Resort: A Study of Constitutional Clemency for Capital
} 
the legal context, requires imposing a lesser punishment than the law allows. That is precisely what the pardon powers authorize: they are, in Blackstone's phrase, the "most amiable" 39 of executive powers. Fourth, the pardon powers are extraordinary, as I said. For the constitution to allow the executive to set aside judicial decisions, something truly important must be at stake. Mercy, which is of inherent value, fits that description (more on this below).

What, then, is mercy? That question is not often considered in the case law, but it is the subject of much thinking in philosophy, and also in legal scholarship. I do not have the space or the expertise to propose a new account of mercy, or to try to resolve age-old disagreements. What I shall do instead is set out the two broad concepts of mercy most prominent in the literature. 40 According to either concept, mercy involves imposing a lesser punishment than is permitted; the two concepts add to this minimal requirement in different ways.

\section{A. Positive Mercy}

The punishment that the law calls for, which is the punishment that judges are to impose, is not always a just punishment. In some cases that is because the punishment the law calls for is too harsh. One ancient concept of mercy is to treat someone justly even though thelaw (or some other social standard) calls for harsher treatment. This is mercy in a positive sense: it is a fitting response to the features of a person's case relevant to justice. ${ }^{41}$

Positive mercy is important in two scenarios. The first is when a law calls for a punishment that is always too harsh, and hence always unjust. Perhaps laws that authorize the death penalty are like this. This scenario could be avoided by changing the law. Even if all laws were just, however, there would still be a role for positive mercy. That is because laws are rules, and rules are generalizations. As generalizations, laws inevitably fail to account for all the variation in the particular cases to which they apply. ${ }^{42}$ Even a just law will, in some cases, call for punishments that are

Crimes in India' (2009) Working Paper Series, Centre for the Study of Law and Governance (J awaharlal Nehru University) 6-9.

39 W Blackstone, Commentaries on the Laws of England (J ohn Murray 1873) 569.

40 I owe this distinction to K Bell, 'Mercy and Criminal Justice' (PhD dissertation, University of North Carolina, 2010) unpublished. The rest of this section draws on her discussion.

${ }^{41}$ The roots of this notion of mercy are found in Seneca's "On Mercy" in Dialogues and Essays (edited and translated by J Davie, OUP 2009), as detailed in Bell (n 39) at $31 \mathrm{ff}$. That mercy in law has traditionally been thought of as the correction of overinclusiveness is explained at length in CAHJ ohnson, "Entitled to Clemency: Mercy in the Criminal Law" (1991) 10 Law and Philosophy 109.

42 On the generality of law and its overinclusiveness, see F Schauer, Playing by the Rules (OUP 1991) c 2. 
too lenient, and in others, punishments that are too harsh. In the latter type of case, positive mercy is appropriate.

One has a duty not to impose unjust and excessive punishments, so one has a duty to show positive mercy. This duty is not a legal duty; it is a moral duty. What this means is that it is morally good to show positive mercy and morally wrong not to show positive mercy. It does not mean that showing positive mercy is the only thing one has a duty to do, or that this duty is never overridden by other duties.

\section{B. Negative Mercy}

Positive mercy is the concept of mercy most familiar to lawyers. The concept of mercy that contemporary philosophers tend to focus on is very different. Here, mercy is understood as imposing a lesser punishment than justice allows. Thus, Alwynne Smart writes that a person who shows mercy "decides that a particular punishment would be appropriate or just, and then decides to exact a punishment of less severity than the appropriate or just one" 43 . This is mercy in a negative sense: it spares a person from harsh treatment in disregard of features of his case relevant to justice. Instead of being motivated by a concern for justice, negative mercy is motivated by a feeling of compassion or sympathy for an offender. ${ }^{44}$

It is morally good to show negative mercy, even though it goes beyond justice. ${ }^{45}$ However, there is no moral duty to show negative mercy. It is morally good to show negative mercy, but not morally wrong or blameworthy not to show negative mercy. Negative mercy is supererogatory, in other words. That negative mercy is supererogatory means that it is morally optional. As J effrie Murphy says, "mercy ... is best viewed as a free gift; an act of grace, love, or compassion that is beyond the claims of right, duty, and obligation" 46 .

That negative mercy is supererogatory has an important consequence. If one acts differently in two situations, which are the same in all relevant ways, then normally one is subject to criticism on rational or moral grounds. One has failed to treat like cases alike. There are exceptions, though, and one exception is for supererogatory acts. ${ }^{47}$ If you give money

${ }^{43}$ A Smart, 'Mercy' (1968) 43 Philosophy 345, 350. See also J Murphy, "Mercy and Legal J ustice" (1986) 4 Social Philosophy and Policy 1; A Duff, 'Mercy' in J Deigh and D Dolinko (eds), Oxford Handbook of thePhilosophy of Criminal Law (OUP 2011) 480. 44 See, e.g., Murphy (n 43) at 3; J Tasioulas, 'Mercy' (2003) 103 Proceedings of the Aristotelian Society 101, 102 .

45 It is morally good to show negative mercy in a pro tanto or prima facie sense, not necessarily in an overall or all things considered sense.

46 Murphy (n 43) 3.

47 G Rainbolt, "Mercy: In Defense of Caprice" (1997) 31 Nous 226 at 232 ("Neither imperfect obligations, merely permitted acts nor supererogation are subject to the principle of sufficient reason"); D Heyd, "Ethical Universalism, Justice, and Favouritism" (1978) 56 Australasian J ournal of Philosophy 25, 28-30. R Harrison in 
to Oxfam you are not thereby obligated to give money to Greenpeace, even if they are equally good causes, you are equally able to help, and so on. In the same way, showing negative mercy in one case does not mean you must, as a matter of morality or rationality, show mercy in like cases.

\section{Recognition of Imperfection}

These two kinds of mercy are very different. Positive mercy is continuous with justice, the source of a moral duty, and need not be motivated by compassion. Negative mercy, by contrast, is a departure from justice, morally optional, and driven by compassion. Positive mercy ought to be shown consistently; negative mercy need not be.

Despite their differences, these two concepts of mercy have much in common. They both involve the moderation of harsh treatment, as I have said. Moreover, they are both a response to imperfection. The actual world is flawed - our institutions and rules are flawed, and we are flawed, too. That is the world in which we live; but there is also the world as we wish it was. Mercy lies between these two worlds, where we can see things as they actually are, but choose to act as if they were better. Our rules are not just, we say; but you, the offender, shall be treated as if they were. That is positive mercy. Or, we say: you have erred, but you shall be treated as if you had not. That is negative mercy. We show mercy for your sake, when the fault is ours; and we show mercy for our own sakes, when the fault is yours. We spare you from a punishment you do not deserve, and we spare ourselves from always focusing on what is worst in the world. Mercy, positive and negative, is thus a kind of mildness in recognition of imperfection.

\section{Which kind of mercy?}

Which kind of mercy, positive or negative, do arts. 72 and 161 authorize? The articles themselves do not say. References in the case law are mainly to positive mercy, but not exclusively. ${ }^{48}$ So, without assuming that both kinds of mercy are authorized, I shall consider the role of caprice with respect to each.

\section{Caprice and Positive Mercy}

Let us suppose that the kind of mercy arts. 72/ 161 authorize is positive mercy. Why does the Constitution authorize the executive to show

"The Equality of Mercy" in Jurisprudence: Cambridge Essays ( $\mathrm{H}$ Gross and R Harrison eds, OUP 1992) takes the stronger view that if mercy is "given for reasons" then it is not mercy at all (109).

48 See, e.g., Kehar Singh (n 12) (negative mercy); Mohinder Singh v State of Punjab (1997) 3 SCC 346 (positive mercy). 
positive mercy? To show positive mercy is to do justice, so it would seem fitting that the power to show positive mercy should go to the institution best able to figure out what justice requires. Surely this is the judiciary, which has appropriate institutional resources; which follows rigorous truth-tracking procedures; and whose personnel has both relevant expertise and experience in making particularistic, impartial decisions. But the Constitution does not give this power to judges. That is puzzling, at first, but I think the rule of law suggests the answer.

The value of the rule of law is, in part, the value of predictability in governance. Standards should be set out in advance and applied as stated. This way, the law's subjects can anticipate the legal consequences of their actions. They can plan their lives according to law. An act of positive mercy involves a departure from a legal standard. It involves the suspension or non-application of a rule or standard setting out a punishment. As a result, acts of positive mercy open a gap between the law as stated and the law as applied.

Opening a gap like this is not always a serious matter. One judge in one case not enforcing the law to show positive mercy does not make the law appreciably less predictable as a whole. Isolated acts of mercy do not imperil the rule of law. But were judges never to enforce laws when they could show mercy instead, the law would be significantly less predictable. In this hypothetical world, judges refuse to apply any unjust criminal law. They refuse to apply criminal laws in all the cases in which they are overinclusive. There might be more justice, in this scenario, but there would be less legal guidance. The rule of law would be greatly undermined.

Between these two extremes - mercy in one case, mercy in every case - is a threshold. Below that threshold the law does rule, but too harshly. There is too little mercy. Above that threshold, the law does not rule enough. There is too much mercy. At that threshold is the "optimal level" of mercy. We cannot hope to identify, let alone arrive at, that optimal level exactly. The question is: how best can we approximate it? If the Constitution gave the power to show mercy to the judiciary instead of the executive, then it would be up to judges to somehow arrange their decisions so that, collectively, they applied the law in enough cases, and showed mercy in enough cases. This is a type of coordination problem, where the right decision for any one judge depends on the decisions other judges make. It is a difficult problem for judges to solve, given the size of the judiciary, the vast number of judicial decisions, and judges' lack of information about each other's decisions. ${ }^{49}$

There is an alternative to judges coordinating themselves: simply centralize the authority to show mercy. And this, of course, is what the

49 On judicial coordination problems and the enforcement of laws, see A Goldman, Practical Rules: When We Need Them and When We Don't (CUP 2002) 42-46; J Brand-Ballard, Limits of Legality: The Ethics of Lawless J udging (OUP 2010) c 10. 
Constitution does. It gives responsibility for deciding when to depart from legal standards to do justice to a small number of people - the President, the Governors, and their advisers. 'Coordination' is facilitated by drastically reducing the number of actors involved in the problem. Understood this way, the justification for giving the most senior members of the executive the authority to show positive mercy is not that they are especially good at figuring out what justice requires - they are not - but that it is easier for them than for judges to anticipate and contain the systemic effects of departing from legal standards. 50

If it is hard for judges to collectively respond to the systemic risks of showing positive mercy, it will be hard for them to collectively respond to the systemic risks of invalidating refusals to show positive mercy, and of imposing duties to make mercy decisions in certain ways. The risk here is that judicial review will create the problem that giving responsibility for positive mercy decisions to the executive should have avoided. Let me put the point another way. The power to set aside legal standards is given to the executive, which concentrates that power, which helps safeguard the rule of law. Judicial review disperses that power. Thus judicial review has the potential to undermine the rule of law despite (ironically) beingjustified in its name.

This danger becomes acute when judges attempt to eliminate capriciousness. Consider the following example. The President is considering applications for mercy by 1000 thieves. The facts of the cases are the same in all relevant respects. Each thief has been sentenced to a harsh punishment. Each sentence is lawful, but unjust. Suppose that pardoning more than 100 of these thieves (or reducing their sentences significantly) would introduce too much unpredictability in the law. It would depart to such a degree from a stated legal standard that it would cease to be a reliable guide to legal consequences. So, the President pardons 100 thieves, and refuses the applications of the others. He (through his advisers) picks who to pardon and who not to pardon randomly, through a lottery.

This is a capricious decision par excellence. It is precisely the kind of decision that the Supreme Court in Maru Ram (and the J CPC in Lewis, and O'Connor J . in Woodard) said is irrational and objectionable. And it is true that, were we to compare the case of any thief who was pardoned to the case of any thief who was not, there would be nothing to justify their different treatment. But that does not mean that pardons ought to have been granted to all 1000 thieves, or refused to all 1000. Pardons ought to have been granted to 100 thieves - and so they were. The different treatment is justified, not by any case-specific reason, but by a systemic consideration of the kind that judges are ill suited to evaluate.

50 Seen this way, the powers under sections 432 and 433 of the Criminal Procedure Code to suspend, remit, and commute sentences are also potentially problematic, insofar as they further disperse the power to depart from legal standards. 
The example is stylized, but the problem is real. The law is frequently unjust, sometimes unavoidably so. If correcting one of the law's injustices meant having to correct every equal or greater injustice, then the law would cease to rule. Thus a degree of capriciousness is the price we pay for balancing two things we value: justice and the rule of law.

\section{CAPrice AND Negative Mercy}

Let us suppose, instead, that arts. 72/ 161 authorizes negative mercy. Built into this assumption are two further assumptions: that the state can show compassion for offenders, and that the state can act in a supererogatory way. ${ }^{51}$ I caution that both of these further assumptions are controversial. If you find them objectionable, then you should think that the (only) kind of mercy authorized by arts. $72 / 161$ will be positive mercy, in which case the argument in the last section will be relevant.

Imagine that two murderers are sentenced to death, as (let us assume) justice demands. The facts of their cases are alike in all relevant respects. Each requests a pardon. Moved by compassion, the President (advised by Cabinet) grants a pardon to Murderer 1 . This is an act of negative mercy. The President is not similarly moved by compassion for Murderer 2, and so refuses his request. The different treatment is clearly capricious, in an ordinary sense of the word. There is little doubt that, as the law stands, an application for judicial review by Murderer 2 would be successful. The Supreme Court repeatedly said in Maru Ram and other cases that pardon decisions must meet the "test of reason", and no reason justifies the different treatment of the two murderers.

It is not obvious what exactly is wrong about the President capriciously granting mercy to Murderer 1 and refusing mercy to Murderer 2. The problem does not seem to lie with rationality or morality. For, as I said earlier, it is not irrational or immoral to show negative mercy in one case but to refuse to show mercy in a like case. Nor does the problem lie with justice. By assumption, Murderer 2's execution would be just; what would be unjust would be to pardon him. Nonetheless, I am reluctant to say - as I imagine readers are - that there is nothing wrong with choosing who lives and who dies on a whim. So let me assume, for the sake of argument, that there is something problematic about capricious grants of negative mercy. ${ }^{52}$

\footnotetext{
51 D Heyd, "Supererogation" (2011) Stanford Encyclopedia of Philosophy, available at http://plato.stanford.edu/ entries/supererogation/, accessed 15 July 2015 (government supererogation is an "understudied issue"). for an argument that government supererogation is impossible, see J Weinberg, "Is Government Supererogation Possible?" (2011) 92 Pacific Philosophical Quarterly 263.

52 One possibility is that treating the two murderers' treatment is objectionable because it is unequal. This view finds support in art. 14 of the Constitution and the Supreme Court's judgment in Maru Ram (n 3) 135 [39], 147 [63]; for a similar line of thought
} 
It does not follow, however, that capriciousness ought to render unlawful a decision to grant or refuse negative mercy. The argument has three steps. First, negative mercy is supererogatory, as I said, and the moral value of a supererogatory act is found partly in its optional character. "Optional" here takes its fullest sense. David Heyd explains:

The agent has full discretion whether to go beyond what is required and makes a personal choice to do so. She is neither under any external constraint (like the law), nor under any internal demands (of rationality or of the ... moral law). In other words, supererogatory behaviour is fully optional. Thus, it would be absurd to force a person to do a supererogatory act, even if that act had extremely beneficial consequences. 53

An act is not supererogatory unless it possesses moral value. It does not possess moral value, in the relevant sense, unless it is fully optional. So, a 'supererogatory' act that is non-optional is not a supererogatory act at all. Put another way, requirements or constraints make the performance of a supererogatory act impossible. For example, giving blood might be a supererogatory act at the moment, but it would not be supererogatory were it legally required.

Now for the second step in the argument. The Supreme Court does not force the executive to grant pardons. The Court lacks the legal authority to do so, and in any case it has not tried. But insisting that the executive reach its decisions under the pardon powers consistently constrains its discretion. Think back to the example above. If the President must make his pardon decisions consistently, then he is free to refuse pardons to both Murderer 1 and Murderer 2, or to grant them both pardons. Once he grants a pardon to Murderer 1, however, he must grant a pardon to Murderer 2; he is not free to refuse, on pain of inconsistency. The President's choice whether to pardon Murderer 2 is therefore not "fully optional", as Heyd would say. It is not a "free act of grace", as Murphy would say. Because his decision is not fully optional, it lacks the moral value associated with supererogatory acts. Together with the point in the last paragraph, it follows that the President is incapable of showing true negative mercy to Murderer 2.

It might seem that this is a price worth paying: perhaps whatever is wrong about deciding who lives and dies on a whim outweighs the value of showing negative mercy. But here is the third and final step in my argument: this is not a choice for judges to make. If constraints are incompatible with showing negative mercy, and if arts. 72/ 161 are meant to empower the executive to show negative mercy, then imposing constraints on the executive's power to show negative mercy would

concerning the Equal Protections Clause, see Stevens J's opinion in Woodard (n 21) 292.

${ }^{53}$ D Heyd, Supererogation: Its Status in Ethical Theory (CUP 1982) 286. 
frustrate the Constitution's aim. That is not something that judges - who are required to apply the Constitution - are entitled to do. Thus, while the courts in Maru Ram and later cases are seeking to uphold the rule of law, by doing so they would seem to have undermined the most fundamental law in India's legal system - the Constitution. 


\section{ConClusion}

I asked: ought a court to demand more justification for a pardon decision than that the executive has made it? A court certainly ought to demand that a pardon be a true exercise of mercy (or perhaps the correction of a legal error). It is entitled to demand that a pardon be issued for a proper motive. A pardon that is the result of nepotism or bribery or the like ought to be rejected, as indeed it would be. Conversely, a court ought to ensure that a pardon has not been refused for reasons that have nothing to do with a lack of compassion or a desire to do justice in other cases. That said, once it has been established that a pardon is an act of mercy, the executive should not be asked to provide any reason for its act. It should not matter why the executive chose this case in which to show mercy, when it could have chosen others. The fact that the executive made the choice it did should be enough for a court, and for the law. This invites capriciousness, in the ordinary sense of the word, but not in the sense that offends the rule of law.

So I conclude that there is that there is nothing wrong, from the perspective of the rule of law, with capricious pardon decisions per se. I acknowledge, however, that there may be contingent practical objections to such decisions. It may be, for example, that if pardon decisions are made capriciously, then people will tend to believe that they have been made for improper motives (nepotism and so forth). It may be valuable to avoid such suspicions, and in that case, valuable to avoid capricious pardon decisions. ${ }^{54}$ I acknowledge the possibility - but I doubt it will always betrue in practice. Even if these suspicions would arise, there are likely to be other ways to address them, such as by making the process of deciding whom to pardon more open and public. In any case, in this scenario, what is objectionable is not capricious pardoning decisions in themselves, but what they are a symptom of.

\footnotetext{
${ }^{54}$ For a similar line of thought, see A Marmor, 'Should Like Cases be Treated Alike?' (2005) 11 Legal Theory 27, 35.
} 